\title{
AN IMMUNOCHEMICAL STUDY OF THE ALBUMINS OF SERUM, URINE, ASCITIC FLUID AND EDEMA FLUID IN THE NEPHROTIC SYNDROME ${ }^{1,2}$
}

\author{
By DAVID GITLIN ${ }^{8}$ AND CHARLES A. JANEWAY
}

\author{
(From the Department of Pediatrics, Harvard Medical School, and the Children's Medical \\ Center, Boston, Mass.)
}

(Submitted for publication October 10, 1951; accepted November 27, 1951)

The serum and urinary proteins in the nephrotic syndrome have been studied by a number of investigators and the divergence of results has given rise to conflicting interpretations concerning the pathogenesis of this disease. With but few exceptions $(1,2)$, there appears to be general agreement that the urinary proteins are derived from the plasma. This was suggested by qualitative immunological tests by Mertens (3), Erben (4), and Müller (5), by optical rotation by Hewitt (6), by racemization by Cavett and Gibson (7), and by a variety of physical-chemical methods by Widdowson (8).

On the other hand, comparisons between the serum proteins of these patients and the serum proteins of normal individuals have indicated marked differences. Goettsch and Reeves (9) studied the serum and urinary proteins in nephrosis through the use of quantitative immuno-chemical procedures, and concluded that the serum proteins in this disease differed immunologically from the normal; in their method, they compared protein levels derived immunochemically with those derived by salt fractionation, the latter being used as the reference standard. Alving and Mirsky (10) found that the albumin fraction separated with ammonium sulfate had a lower cystine content than did similar fractions of normal serum, but upon further purification, the resulting nephrotic serum albumin had the same cystine content as normal serum albumin. Albanese, Davis, Smetak and Lein (11), using ammonium sulfate fractions, found an abnormal distribution of amino acids in the plasma proteins of nephrotic patients.

1 Presented before the Society for Pediatric Research at Atlantic City, May 2, 1951.

2. Supported by grants from the National Institutes of Health, U. S. Public Health Service.

3 Postdoctorate Research Fellow of the National Institutes of Health.
With the introduction of the Tiselius apparatus, the Howe method for the separation of albumin and globulins in serum and urine was shown to be in serious error, particularly where the proportion of albumin was low (12). Longsworth and MacInnes (13) and Luetscher (12) showed that the albumin content was very low in nephrotic serum and that the pattern of the urinary proteins in the nephrotic syndrome resembled that of normal serum. These findings would serve to explain many of the abnormalities of the "albumins" obtained by salt fractionation of nephrotic serum. However, Luetscher did observe that in nephrotic serum and urine the ratio of the two components of albumin separated by electrophoresis at $\mathrm{pH} 4.0$ was reversed from the "normal" and he postulated an abnormality in the metabolism of albumin in this syndrome.

The present study is an attempt to compare by immunochemical characterization the albumins of the plasma, urine, ascitic and edema fluids of nephrotic patients with crystallized albumin obtained from the pooled plasma of normal humans $(14,15)$.

\section{MATERIALS AND METHODS}

Patients: Eleven children with the nephrotic syndrome were selected for study. The pertinent aspects of their disease are presented in Table $I$. Their ages ranged from 19 months to 5.3 years, and the duration of illness from the time of onset to the time of study was from two months to 24 months. Serum was obtained from each of the 11 patients, ascitic fluid from eight patients and an additional patient, D. D. R., urine from six and edema fluid from two. Serum was also obtained from a 12th child, R. S., who had chronic glomerulonephritis with hypertension and congestive failure with anasarca.

Antisera: The antigen employed throughout this study was crystallized human serum albumin, preparation Decanol 10 (15), crystallized from fraction V obtained from the pooled plasma of normal adults by low-temperature ethanol-water fractionation (14). One group of five rabbits was given three subcutaneous injections of crystal- 
lized human serum albumin per week for four weeks, 15 mg. per kilo body weight per injection, and then bled by cardiac puncture 10 days after the last injection. A second group of six rabbits was given an albumin-aluminum hydroxide suspension subcutaneously, one injection of $25 \mathrm{mg}$. albumin per kilo body weight every 12 days for four injections, and these animals were bled by cardiac puncture 14 days after the last injection. The albumin-aluminum hydroxide suspension was prepared by dissolving $1.25 \mathrm{gm}$. crystallized human serum albumin in $5 \mathrm{ml}$. saline and then adding this solution to $45 \mathrm{ml}$. washed aluminum hydroxide gel.4 The gel was washed prior to the addition of the albumin by adding to it an equal volume of $0.15 \mathrm{M}$ saline, allowing the gel to sediment overnight, decanting and rewashing the precipitate with $0.15 \mathrm{M}$ saline once again. The sera of the animals within each group were pooled and the sera stored at $-30^{\circ}$ C. until use.

The preparation of the horse antiserum vs. human serum albumin, used in this study, has been described (16). The crystallized human serum albumin employed as an antigen in the horse was the same preparation used for immunizing the rabbits.

All of the antisera were found to be specific for human serum albumin and to contain no detectable precipitins for $\gamma$-globulins, $\beta$-lipoprotein, or $\beta_{1}$-metal combining globulin obtained from human plasma. In addition, after adsorption with crystallized human serum albumin, these antisera did not precipitate with any dilution of whole human serum, again demonstrating the probable absence of precipitating antibody for any protein of human plasma other than albumin.

Immunochemical analysis of body fluids: Each of the body fluids studied was appropriately diluted with $0.15 \mathrm{M}$ sodium chloride solution, so that a series of antigen concentrations was obtained that would cover all the zones of inhibition and precipitation when aliquots were reacted with the rabbit and horse antisera employed. Antigenrabbit antiserum reaction mixtures were prepared by mixing $0.5 \mathrm{ml}$. of each of the serial dilutions of a given body fluid sample with $1.0 \mathrm{ml}$. aliquots of rabbit antiserum. The mixtures were incubated at $37^{\circ} \mathrm{C}$. for one hour, then $1^{\circ} \mathrm{C}$. for 24 hours. The precipitate was washed twice with cold $0.15 \mathrm{M}$ saline, employing centrifugation at 4,000 r.p.m. at $0^{\circ}$ C. for 20 minutes to recover the precipitate. The amount of specific precipitate was measured by the spectrophotometric method (17).

In using the horse antiserum system, $1.0 \mathrm{ml}$. aliquots of suitable dilutions of the given sample of body fluid to be studied were mixed with $1.0 \mathrm{ml}$. aliquots of horse antiserum, the mixtures incubated at $37^{\circ} \mathrm{C}$. for one hour and then at $0^{\circ} \mathrm{C}$. for three days. The precipitate was recovered by centrifugation at $0^{\circ}$ C. at 4,000 r.p.m. for 30 minutes, washed twice with cold saline, and measured spectrophotometrically.

4 The aluminum hydroxide gel employed was Creamalin 8 , a suspension prepared by Winthrop-Stearns Company.
All antisera were clarified immediately before use by filtration through an asbestos filtering pad. Appropriate dilutions of crystallized human serum albumin in 0.15 M saline were employed as standards for obtaining the standard antigen-antibody reaction curves. The final volume of the reaction mixture and the amount of antiserum in the mixture were kept constant and the amount of antigen added to the system in a constant volume was varied.

The antigen-antibody curves were constructed in the conventional manner. The amount of antigen added to a constant volume of antiserum was plotted along the abscissa and the amount of specific precipitate obtained from the antigen-antiserum mixture was plotted, as optical density, along the ordinate. Since there was no method available for the accurate $s$ estimation of albumin in body fluids where the proportion of albumin is low such as nephrotic serum, edema fluid and ascitic fluid, the absolute amount of antigen in these body fluids added to the antiserum, and hence the absolute units employed along the abscissa, could not be ascertained. Therefore, the amount of antigen in the nephrotic fluid studied was plotted on a relative scale along the abscissa, selecting as unity that amount of nephrotic fluid giving a specified quantity of specific precipitate, in terms of optical density, with the rabbit antiserum. The specified optical density selected as the reference point was held constant for all curves including that obtained with crystallized normal serum albumin and thus all curves with a given rabbit antiserum were adjusted to the same scale. In all the figures presented the relative scale has been reconverted to $\mathrm{mg}$. of albumin, since the absolute amounts of crystallized human serum albumin added to the reaction mixtures to obtain the standard curves were known.

The assumptions inherent in such a procedure are first, that antigens giving superimposable precipitation curves with a given antiserum under the conditions of these experiments are immunologically identical, and second, that antigens giving precipitation curves which differ in shape from those of the standard must differ from it im-

5 The error in estimation of albumin in these fluids would have to be less than about $5 \%$ (of the amount of albumin present) if any significance were to be attached to the immunochemical results. The only method approaching this accuracy at low albumin concentrations at this point in the investigation was electrophoresis; the statistical error in the interpretation of the electrophoretic diagram would be about $1 \%$ but at albumin levels of about $10 \%$. This would mean a $10 \%$ error in the estimation of the amount of albumin present. The error due to interference by $\alpha$ and $\beta$ globulins would also be significant (18). In addition, the absolute amount of total protein present would have to be measured and any method adopted would be subject to serious error due to the high lipid content of all the sera studied and the abnormal ratio of the protein components $(14,19)$. This error coupled with the errors in interpretation of the electrophoretic pattern would make this procedure hazardous for absolute values at low albumin: total protein ratios. 
TABLE I

\begin{tabular}{|c|c|c|c|c|c|c|c|c|}
\hline \multirow[b]{2}{*}{ Patient* } & \multirow[b]{2}{*}{$\begin{array}{c}\text { Age } \\
\text { (vears) }\end{array}$} & \multirow[b]{2}{*}{$\underset{(m s . \%)}{\text { NPNt }}$} & \multirow[b]{2}{*}{$\begin{array}{l}\text { Blood } \\
\text { pressure }\end{array}$} & \multirow[b]{2}{*}{$\begin{array}{l}\text { Grosat } \\
\text { hematuria }\end{array}$} & \multirow{2}{*}{$\begin{array}{c}\text { Duration of } \\
\text { illiness } \\
\text { (months) }\end{array}$} & \multicolumn{3}{|c|}{ Concentration $\$$ of albumin in } \\
\hline & & & & & & $\underset{(\mathrm{sm} . \%)}{\text { Serum }}$ & $\begin{array}{c}\text { Arcitic } \\
\text { fluid } \\
(\mathrm{gm} . \%)\end{array}$ & $\begin{array}{c}\text { Edema } \\
\text { fluid } \\
\text { (sm. \%) }\end{array}$ \\
\hline $\begin{array}{l}\text { J. R. } \\
\text { J. S. M. } \\
\text { C. H. } \\
\text { K. P. } \\
\text { M. P. } \\
\text { J. F. } \\
\text { W. G. } \\
\text { L. N. } \\
\text { R. O. } \\
\text { B. P. } \\
\text { D. D. R.\|l } \\
\text { J. K. }\end{array}$ & $\begin{array}{ll}2 & 11 / 12 \\
2 & 8 / 12 \\
3 & 10 / 12 \\
4 & 4 / 12 \\
4 & 5 / 12 \\
2 & 2 / 12 \\
5 & 4 / 12 \\
4 & 8 / 12 \\
3 & 1 / 12 \\
1 & 7 / 12 \\
1 & 11 / 12 \\
2 & 5 / 12\end{array}$ & $\begin{array}{l}20-47 \\
21-54 \\
31-41 \\
30-60 \\
26-49 \\
33-52 \\
36-65 \\
46-104 \\
30-37 \\
32-34 \\
28-39\end{array}$ & $\begin{array}{l}106 / 64 \\
106 / 68 \\
110 / 70 \\
104 / 70 \\
110 / 70 \\
108 / 72 \\
100 / 60 \\
106 / 70 \\
114 / 76 \\
108 / 70 \\
110 / 70 \\
90 / 48\end{array}$ & $\begin{array}{l}0 \\
0 \\
0 \\
+ \\
0 \\
0 \\
0 \\
+ \\
0 \\
0 \\
0 \\
0\end{array}$ & $\begin{array}{r}15 \\
13 \\
9 \\
13 \\
24 \\
9 \\
11 \\
24 \\
2 \\
3 \\
5 \\
12\end{array}$ & $\begin{array}{l}0.60 \\
0.28 \\
0.32 \\
0.29 \\
0.42 \\
0.16 \\
0.09 \\
0.46 \\
0.27 \\
0.22 \\
0.51\end{array}$ & $\begin{array}{l}0.023 \\
0.006 \\
0.009 \\
0.012 \\
0.005 \\
0.005 \\
0.044 \\
0.006 \\
0.018\end{array}$ & 0.001 \\
\hline R. S. I & $711 / 12$ & $116-155$ & $150 / 112$ & 0 & 18 & 1.57 & & \\
\hline
\end{tabular}

* All patients had anasarca and ascites at time of study.

$\dagger$ Range during illness.

$\$$ Microscopic hematuria to some extent was observed in most patients at some time during their illness.

8 As determined immunochemically employing rabbit antiserum. Specimens of serum, and of ascitic and edema fluids were not necessarily obtained simultaneously.

II Only ascitic fluid was studied in D. D. R.

I R. S. is a patient with chronic glomerulonephritis, hypertension and congestive heart failure.

munochemically, at least in part. These assumptions seem to be justified by immunological experience with other antigen-antibody systems. In the case of human serum albumins which have been markedly altered by conjugation with azodyes, we have shown $(20)$ that these modified proteins will still precipitate with antisera against human serum albumin but with a different precipitation curve from that obtained with the native protein.

In those instances where the proportion of albumin was known to be as high as $85 \%$ to $95 \%$ of the proteins present, as in the urine protein samples, the percentage of albumin was determined electrophoretically; the total protein was calculated by dialyzing the fractionated urinary proteins against saline and then saline-buffer (phos-

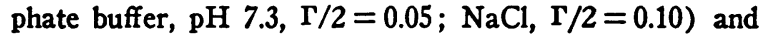
determining the difference in the dry weights of aliquots of the fluid inside and outside the membrane. In the case of the urine samples, therefore, the figures along the abscissa represent the actual amount of albumin as calculated for both the albumin standards and the urinary proteins.

Preparation of materials for analysis: Since the protein content of edema fluid and ascitic fluid proved too low to permit adequate characterization, these fluids were concentrated 10 to 30 -fold by placing them in long lengths of narrow dialyzing tubing and suspending the tubing at $1^{\circ} \mathrm{C}$. for four to seven days. The concentrated fluids were then dialyzed against $0.15 \mathrm{M}$ saline and finally, several changes of saline-buffer.

To prevent denaturation of the albumin in urine by its interaction with other urinary constituents, the urinary proteins were rapidly separated from the urine by precipitation with ethanol at low temperatures employing
Method 10 (21) with slight modifications. ${ }^{\circ}$ The urinary albumin was extracted from the protein precipitate with $19 \%$ ethanol at $\mathrm{pH} 5.8$; after several precipitations and extractions, the albumin fraction was lyophilized.

Normal human serum was rendered low in its proportion of albumin relative to the other serum proteins by precipitation and extraction with alcohol by Method 10 (21), the reconstituted serum representing a solution of the initial precipitate of this technique. Albumin separated from the albumin-rich supernatant of this fractionation procedure was found to be identical both immunochemically and physico-chemically with the crystallized albumin employed as an antigen in these studies, thus making it unlikely that specific albumin components rather than the major portion of the total albumin had been removed from these normal sera. Electrophoretic analyses of normal sera so prepared revealed low albumin : total protein ratios very similar to those of sera from nephrotic patients. Precipitation curves of rabbit and horse antisera were obtained with these low-albumin "normal" sera as controls for possible interference in the precipitation of albumin with either type of antibody by specific or non-specific interaction of albumin with other proteins in human serum.

\section{RESULTS}

The results are given in a series of figures which compare the experimental points obtained with various materials with the standard curve for crystallized normal human serum albumin. In

\footnotetext{
- With the collaboration of Dr. Lewis Barness.
} 


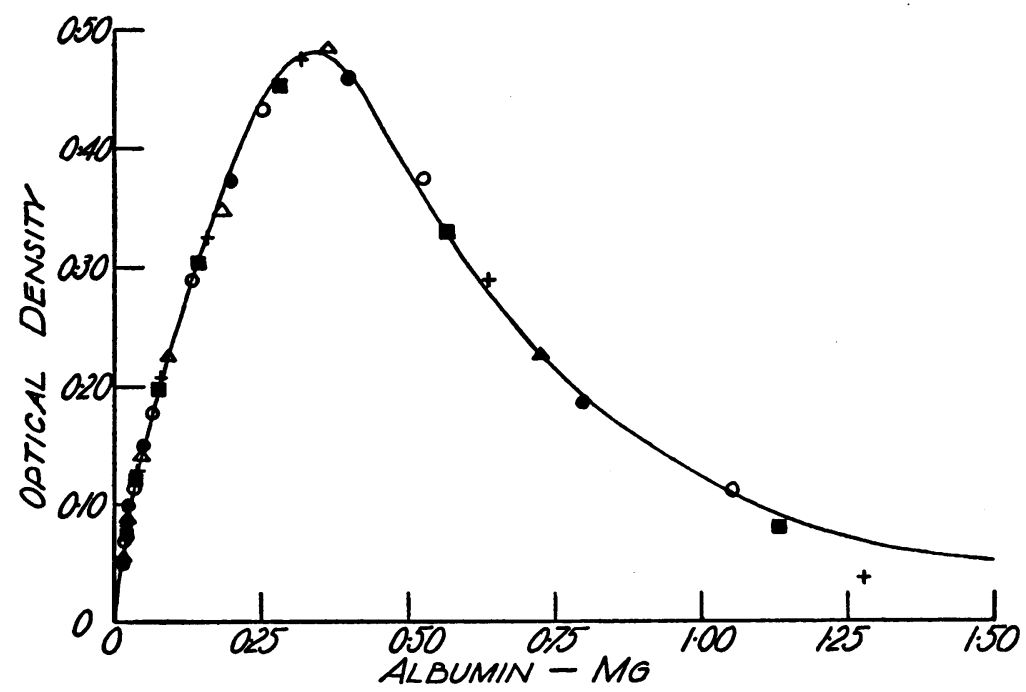

Fig. 1. The Precipitation Curves Obtained in the Reaction between a Given Rabbit Antiserum vs. Normal human Serum albumin and Several Nephrotic Sera

In this figure and in all subsequent figures, the solid line represents the precipitation curve obtained in the reaction between the antiserum and crystallized normal human serum albumin, and the symbols represent values for the specimen from a particular patient.
O M. P.
$\triangle$ K.P.
- C. H.
L. N.
+ J. K.

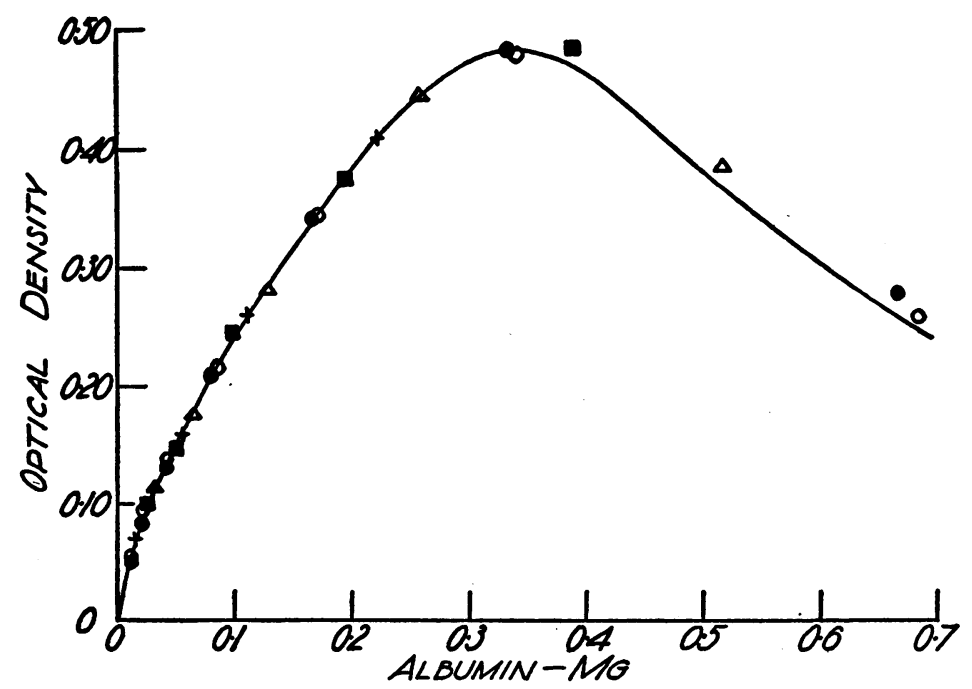

Fig. 2. The Precipitation Curves Obtained in the Reaction between a Given Rabbit Antiserum vs. Normal human Serum Albumin and Several Nephrotic Sera

In the case of J. F., a paracentesis was performed and the patient lost most of his edema fluid between the time of the first and last specimens studied.
J. F. $4 / 26 / 50$
O J.F. $4 / 29 / 50$
R. 0
+ W. G. 
all these figures the solid line indicates the standard curve and the symbols represent the experimental points obtained and plotted as described above, each symbol representing material from a particular patient. Estimated concentrations of albumin in various fluids obtained from different patients are reported in Table $I$.

\section{A. Characterization with Rabbit Antisera}

1. Albumins of serum. The precipitation curves obtained by reacting the rabbit antisera with nephrotic sera were indistinguishable over all zones of precipitation and inhibition from those obtained

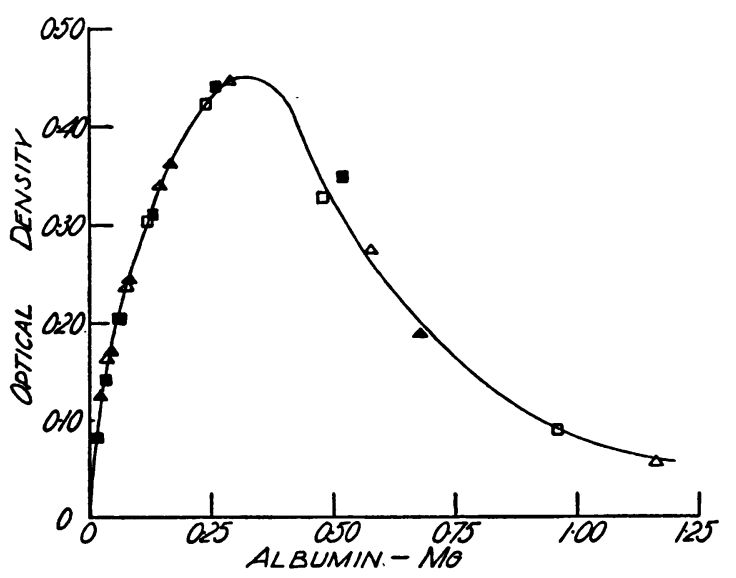

Fig. 3. The Precipitation Curves Obtained in the Reaction between a Given Rabbit ANtiserum vs. Normal Human Serum Albumin and Several NePHROTIC SERA

Included is the precipitation curve obtained with the serum of a patient with severe glomerulonephritis, R. S.
$\Delta \mathrm{J} . \mathrm{R}$.
R.S.
$\triangle$ J.S. M.
B. P.

when reacting the same antiserum with its homologous antigen, crystallized human serum albumin, as shown in Figures 1 to 3 . Serum samples were obtained from a single patient, J. F., over a period of several days during which a paracentesis was performed and was followed by drainage through the paracentesis wound, loss of all edema, and a rise in serum albumin from $0.16 \mathrm{gm} . \%$ to 0.28 gm. $\%$ in three days. The albumins in the three sera from this patient were identical immunochemically, as illustrated in Figure 2. Patient R. $\mathrm{S}$. had chronic glomerulonephritis, hypertension with congestive failure, and a substantially higher

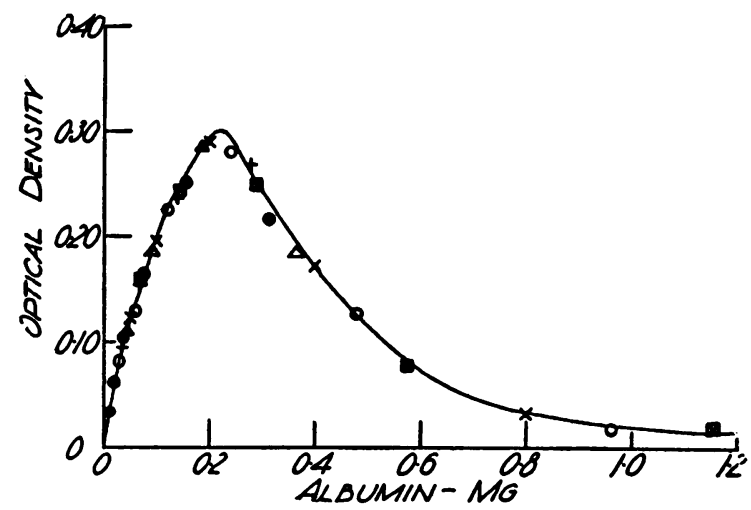

Fig. 4. The Precipitation Curves Obtained with a Given Rabbit Antiserum and Several Ascitic Fluids, an Edema fluid and a Normal Serum Rendered Low in Albumin Content
Ascitic fluids:
D. D. R.
R. 0 .
+ J.S. M.
$\boldsymbol{Q} \mathrm{J} . \mathbf{R}$.

Edema fluid:

$\triangle$ C. $H$.

Low albumin, "normal serum No. 1": $X$

serum albumin level (1.57\%) than those of the other patients, but the points determined for his serum albumin fell on the standard curve (see Figure 3).

2. Albumins of ascitic fluid and subcutaneous edema fluid. The precipitation curves for these albumins are shown in Figure 4. They are identical with the standard curve obtained with crystallized normal human serum albumin.

3. Albumins of urine. The urinary albumin'

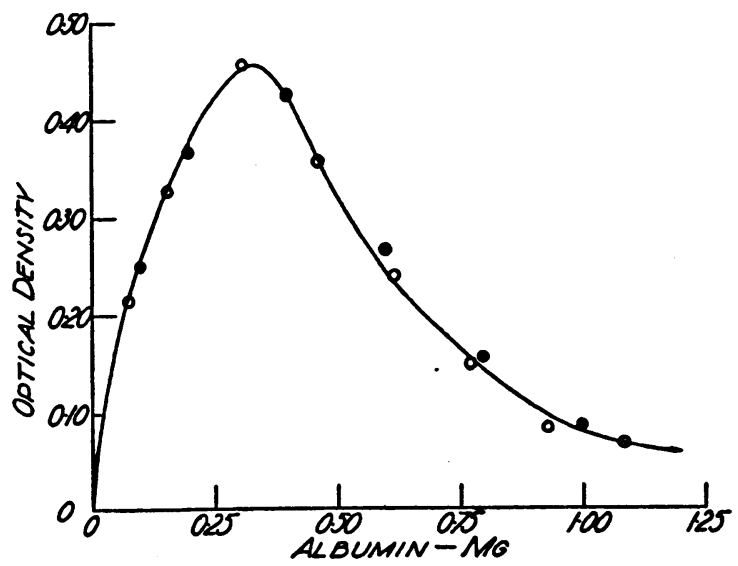

Fig. 5. The Precipitation Curves Obtained in the Reaction between a Given Rabbit Antiserum vs. Normal Human Serum Albumin and Two Samples of URINARY ALBUMIN

O J.S. M.

- C. H. 


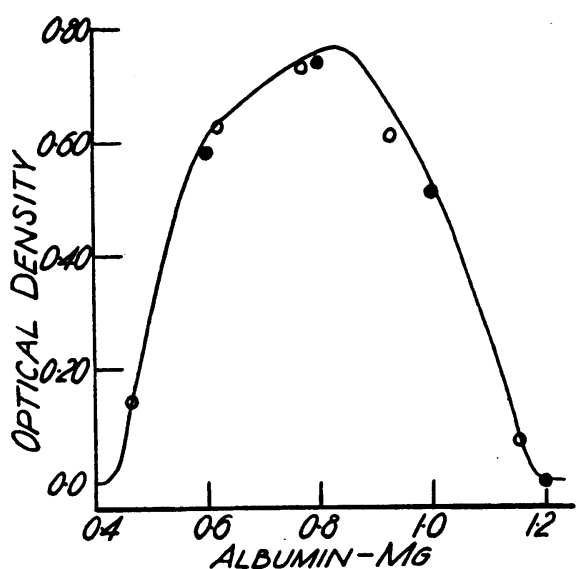

Fig. 6. The Precipitation Curves Obtained in the Reaction between Horse ANTI-Albumin and the Two Samples of Urinary Albumin of Figure 5

curves were identical with those obtained with normal serum albumin when reacted with rabbit antisera, as shown in Figure 5. It should be noted that the amount of urinary albumin added to the antiserum was calculated from electrophoretic and dry weight data and the abscissae in this figure, therefore, represent absolute values.

\section{B. Characterization with Horse Antiserum}

The curves obtained with two nephrotic urinary albumins were identical with the standard curve using horse antiserum as shown in Figure 6.

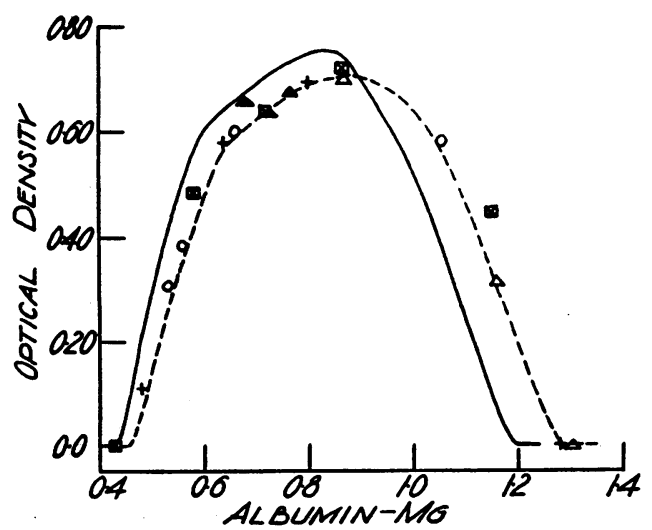

Fig. 7. The Precipitation Curves Obtained in the Reaction between Horse Anti-albumin and Several Nephrotic Fluids

Sera:

O M.P. + J. K.

Q J.R.

$\Delta \mathrm{J} . \mathrm{R}$.

$\triangle$ J.S. M.

Ascitic fluid: Low albumin, "normal serum No. 1": dashed line.
However, serum and ascitic fluid albumins in the human albumin-horse anti-albumin system gave slightly different curves from those obtained with crystallized normal serum albumin, as illustrated in Figure 7. It is important to note at this time that the albumin contents of these nephrotic fluids were estimated from the rabbit antiserum curves (17) and plotted as "absolute" values along the abscissa for the horse antiserum system. The horse serum curves for nephrotic serum and ascitic fluid albumins were identical, however, with those obtained by reacting the horse antiserum with lowalbumin "normal" human serum as indicated in Figure 7. To keep the procedure uniform, the amount of albumin in the low-albumin "normal" serum used along the abscissa in Figure 7 was estimated by the rabbit antiserum method and the rabbit curve for this serum is shown in Figure 4.

\section{DISCUSSION}

From the data presented, there does not appear to be any immunochemical abnormality of the circulating serum albumin or of the albumin found in the edema fluid, ascitic fluid or urine of these patients. The thesis, therefore, that albuminuria in the nephrotic syndrome represents the excretion (11) or retention (9) of abnormal circulating serum albumin is not substantiated by the data reported here. It would appear instead that the albuminuria is related primarily to the pathological defect in the kidney. This is in accord with the finding that patients with the nephrotic syndrome retain only a small portion of intravenously injected albumin prepared from pooled normal plasma (22).

The low albumin levels we have found in the sera of patients with the nephrotic syndrome during the edematous phases of this disease agree well with those reported in the electrophoretic studies of Longsworth and MacInnes (13) and Luetscher (12). The higher serum albumin level found in the single patient with severe chronic glomerulonephritis is in accord with the findings of Heymann and Lund (23): in experimental nephrotic syndome in rats, they found marked hypoproteinemia in the acute phase, but gradual improvement in this finding occurred as the disease progressed.

The simultaneous precipitin studies with rabbit and horse antisera were interesting in that the horse system appeared to measure less albumin 
in a given sample than did the rabbit serum. At least three explanations seem possible. It may be postulated that the horse and rabbit antisera react differently with different albumin components and, therefore, human serum albumin is immunochemically heterogeneous. That crystallized normal human serum albumin is physico-chemically heterogeneous is beyond question (15). However, since crystallized normal serum albumin was used for the standard curves for both the rabbit and horse systems, one must also postulate that the ratio of immunochemical components in the crystallized normal serum albumin differed from the ratio of these components in both normal and nephrotic sera. An alternative hypothesis is that serum albumin in its native state interacts with other serum proteins sufficiently to interfere with its precipitation by horse antiserum but not by rabbit antiserum. Interaction among the serum proteins has been repeatedly demonstrated. That the rabbit and horse systems differ in their reactivity with human serum albumin has also been demonstrated (20). A third possibility is that the rabbit antisera interacted with another plasma protein in addition to albumin. However, precipitins for plasma proteins other than albumin could not be demonstrated in the antisera used.

The albumin concentrations obtained with the horse antiserum system as estimated from the precipitation curves were about $5 \%$ to $10 \%$ lower than those obtained with the rabbit system. When the albumin levels being measured are considered, it appears that the horse system is as reasonably accurate as electrophoresis for the estimation of serum albumin at low levels and hence substantiates earlier findings (16).

It should be pointed out that the antisera used were all prepared against and standardized with a preparation of human serum albumin, obtained from the pooled plasma of several hundred normal human adults, by precipitation from an alcohol-water mixture at low temperature with controlled $\mathrm{pH}$, ionic strength, and protein concentration and subsequently by crystallization with a small amount of decanol and by two recrystallizations. It might be argued that such an albumin preparation might not represent the total albumin of normal human plasma and that another albumin may have been present in normal plasma, in nephrotic plasma or in both which would not react with antibody prepared against such a crystallized albumin. Under such circumstances this albumin component could have escaped detection throughout these studies. Against this is the close agreement between values obtained for the albumin content of nephrotic sera and urine by immunochemical analysis and those obtained by the electrophoretic method. Moreover, it is extremely unlikely that two proteins, derived from the same source and with identical physico-chemical properties, would not cross-react at all when studied immunochemically (20).

\section{SUMMARY}

An immunochemical study was made of the serum albumin of 11 children with the nephrotic syndrome employing rabbit and horse antisera. The albumins of the ascitic fluid from eight of these patients and an additional patient, of the urine from six patients and of the edema fluid from two patients were studied also. In all instances, the nephrotic albumin was immunochemically indistinguishable from crystallized normal human serum albumin. The average albumin level in the serum of the nephrotic patients studied, as determined immunochemically, was $0.3 \mathrm{gm} . \%$, with levels ranging from $0.09 \mathrm{gm} . \%$ to about $0.6 \mathrm{gm} . \%$.

The serum albumin of a patient with severe chronic glomerulonephritis was also immunochemically indistinguishable from normal serum albumin. However, the serum albumin concentration in this patient was $1.57 \mathrm{gm} . \%$.

\section{ACKNOWLEDGMENT}

The authors wish to thank Dr. Walter L. Hughes, Jr. for his invaluable advice and encouragement.

\section{REFERENCES}

1. Thomas, W. A., Schlegel, K. W., and Andrews, E., Urinary proteins not originating in blood. Arch. Int. Med., 1928, 41, 445.

2. Thomas, W. A., Source and role of urinary protein in nephritis. J. A. M. A., 1931, 97, 1055.

3. Mertens, V. E., Ein biologischer Beweis für die Herkunft des Albumen im Nephritisharn aus dem Blute. Deutsche med. Wchnschr., 1901, 27, 161.

4. Erben, F., Studien uber Nephritis. Ztschr. f. klin. Med., 1903, 50, 441.

5. Müller, F., Bezeichnung und Begriffsbestimmung auf dem Gebiet der Nierenkrankheiten. Veröff. Mil.San., 1917, 65, 21. 
6. Hewitt, L. F., Optical rotatory power and dispersion of proteins. Biochem. J., 1927, 21, 216.

7. Cavett, J. W., and Gibson, R. B., A comparison of the racemization curves for urinary, edema fluid, and blood plasma proteins. J. Clin. Invest., 1931, 10, 857.

8. Widdowson, E. M., A comparative investigation of the urine and serum proteins in nephritis. Biochem. J., 1933, 27, 1321.

9. Goettsch, E., and Reeves, E. B., Observations on the nature of the serum proteins in nephrosis. J. Clin. Invest., 1936, 15, 173.

10. Alving, A. S., and Mirsky, A. E., The nature of plasma and urinary proteins in nephrosis. J. Clin. Invest., 1936, 15, 215.

11. Albanese, A. A., Davis, V. I., Smetak, E. M., and Lein, M., The significance of the amino acid composition of the proteins excreted by the nephrotic child. J. Lab. \& Clin. Med., 1949, 34, 326.

12. Luetscher, J. A., Jr., Electrophoretic analysis of plasma and urinary proteins. J. Clin. Invest., 1940, 19, 313.

13. Longsworth, L. G., and MacInnes, D. A., An electrophoretic study of nephrotic sera and urine. $J$. Exper. Med., 1940, 71, 77.

14. Cohn, E. J., Strong, L. E., Hughes, W. L., Jr., Mulford, D. J., Ashworth, J. N., Melin, M., and Taylor, H. L., Preparation and properties of serum and plasma proteins. IV. A system for the separation into fractions of the protein and lipoprotein components of biological tissues and fluids. J. Am. Chem. Soc., 1946, 68, 459.

15. Cohn, E. J., Hughes, W. L., Jr., and Weare, J. H., Preparation and properties of serum and plasma proteins. XIII. Crystallization of serum albumins from ethanol-water mixtures. J. Am. Chem. Soc., 1947, 69, 1753.
16. Gitlin, D., Davidson, C. S., and Wetterlow, L. H., The quantitative estimation of serum albumin in human body fluids by direct titration with specific horse antiserum. J. Immunol., 1949, 63, 415.

17. Gitlin, D., Use of ultraviolet absorption spectroscopy in the quantitative precipitin reaction. J. Immunol., 1949, 62, 437.

18. Armstrong, S. H., Jr., Budka, M. J. E., and Morrison, K. C., Preparation and properties of serum and plasma proteins. XI. Quantitative interpretation of electrophoretic schlieren diagrams of normal human plasma proteins. J. Am. Chem. Soc., 1947, $69,416$.

19. Armstrong, S. H., Jr., Budka, M. J. E., Morrison, K. C., and Hasson, M., Preparation and properties of serum and plasma proteins. XII. The refractive properties of the proteins of human plasma and certain purified fractions. J. Am. Chem. Soc. 1947, 69, 1747.

20. Gitlin, D., Latta, H., Batchelor, W. H., and Janeway, C. A., Experimental hypersensitivity in the rabbit; disappearance rates of native and labelled heterologous proteins from the serum after intravenous injection. J. Immunol., 1951, 66, 451.

21. Cohn, E. J., Gurd, F. R. N., Surgenor, D. M., Barnes, B. A., Brown, R. K., Derouaux, G., Gillespie, J. M., Kahnt, F. W., Lever, W. F., Liu, C. H., Mittelman, D., Mouton, R. F., Schmid, K., and Uroma, E., A system for the separation of the components of human blood; quantitative procedures for the separation of the protein components of human plasma. J. Am. Chem. Soc., 1950, 72, 465.

22. Luetscher, J. A., Jr., The effect of a single injection of concentrated human serum albumin on circulating proteins and proteinuria in nephrosis. $\mathrm{J}$. Clin. Invest., 1944, 23, 365.

23. Heymann, W., and Lund, H. Z., Nephrotic syndrome in rats. Pediatrics, 1951, 7, 691. 